\title{
Evaluation of an Irrigation Scheduling Model for Drip-irrigated Potato in Southeastern United States
}

\author{
Eric Simonne ${ }^{1}$, Nadia Ouakrim ${ }^{2}$, and Arnold Caylor ${ }^{3}$ \\ Horticultural Sciences Department, IFAS, 1241 Fifield Hall, Gainesville, \\ FL 32611-0692
}

Additional index words. Solanum tuberosum, pan evaporation, crop factor, water balance

\begin{abstract}
Potato (Solanum tuberosum L.) is often produced as a nonirrigated crop in the southeastern United States. This practice makes tuber yields dependent on rainfall pattern and amount. An irrigation scheduling method based on a water balance and daily class A pan evaporation (Ep) was evaluated during 1996 and 1998 on a Hartsells fine sandy loam soil for 'Red LaSoda' potatoes. Planting dates were 9 and 7 Apr. in 1996 and 1998, respectively, and standard production practices were followed each year. The model tested was $(13 \mathrm{DAH}+191) * 0.5 \mathrm{ASW}=\mathrm{D}_{\mathrm{DAH}-1}+\left[\mathrm{Ep} *\left(0.12+0.023 \mathrm{DAH}-0.00019 \mathrm{DAH}^{2}\right)-\mathbf{R}_{\mathrm{DAH}}\right.$ - $\mathrm{I}_{\mathrm{DAH}}$, where DAH was days after hilling, ASW was available soil water $(0.13 \mathrm{~mm} / \mathrm{mm})$, $D$ was soil water deficit $(\mathrm{mm}), \mathbf{R}$ was rainfall $(\mathrm{mm})$, and I was irrigation $(\mathbf{m m})$. Controlled levels of water application ranging between $0 \%$ and $200 \%$ of the model rate were created with drip tapes. Four and seven irrigations were scheduled in 1996 and 1998, respectively. For both years, no interaction between irrigation regime and nitrogen rate was observed. Irrigation rate significantly influenced total yield and marketable yield $\left(R^{2}>0.88, P<0.01\right)$. Highest total yields occurred at $99 \%$ and $86 \%$ of the model rate in 1996 and 1998 , respectively. These results show that supplementing rainfall with irrigation and controlling the amount of water applied by adjusting irrigation to actual weather conditions increased potato marketable yield. Over the 2 -year period of the study, an average additional profit of $\$ 563 / \mathrm{ha} /$ year was calculated from costs and returns due to irrigation, suggesting that drip-irrigation may be economical for potato production.
\end{abstract}

Most of the 2500 ha of potato (Solanum tuberosum L.) grown in Alabama are redskinned and are produced as a spring crop for fresh market. For a typical spring production, seed pieces are planted during early March. The crop is hilled twice in April, and harvested in June. Rainfall amounts during the spring are usually adequate for potato production. However, uneven rainfall distribution may result in a prolonged drought period during tuber initiation and bulking. Water shortages at this stage of plant development have been shown to reduce shoot growth (Curwen, 1993; Stark et al., 1987; Weisz et al., 1994), and tuber yield (Miller and Martin, 1985, 1987; Shock et al., 1998; Stark and McCann, 1992; Wolfe et al., 1983), as well as quality (Kincaid et al., 1993; Shock et al., 1993).

Scheduling irrigation is determining when to start irrigation, and how much to apply. As an alternative to the empirical "feel and see" methods, several irrigation scheduling methods for potato have been developed based on

Received for publication 15 Aug. 2000. Accepted for publication 7 May 2001. Journal paper No. FR07720 of the Florida Agricultural Experiment Station. ${ }^{1}$ Assistant Professor.

${ }^{2}$ Former Exchange Visitor from the Ecole National Superieure Agronomique de Toulouse, France to the Dept. of Horticulture, 101 Funchess Hall, Auburn Univ., AL 36849-5408.

${ }^{3}$ AAES Superintendent, North Alabama Horticulture Research Station, Cullman, Ala. weather, soil, or plant data. Growth-stage specific coefficients $(\mathrm{Kc})$ and the water balance method provided a valuable tool in scheduling overhead irrigation of 'Russet Burbank' potatoes in the Columbia Basin of Oregon (Hane and Pumphrey, 1984). The reported Kc values ranged between 0.3 at emergence to 0.8 during maximum leaf area, and declined as the crop matured. In Idaho, Kincaid et al. (1993) used two irrigation frequencies (one and three times a week) and three irrigation amounts (80\%, $100 \%$, and $120 \%$ of evapotranspiration) calculated from the modified Penman method associated with crop coefficient curves. They found that neither frequency nor amount significantly affected tuber yields.

Irrigation scheduling can also be based on maximum allowable soil water tension (SWT) or canopy temperature. Total and US\#1 yields were reduced when deficit irrigation was applied at $80 \mathrm{kPa}$ as compared with $60 \mathrm{kPa}$ (Shock et al., 1998). When maximum SWT was $80 \mathrm{kPa}$, applying irrigation amounts equal to $100 \%$ of the accumulated reference evapotranspiration throughout potato growth, $70 \%$ throughout potato growth, or $70 \%$ through bulking and $50 \%$ thereafter, further reduced tuber yield. Stockle and Hiller (1994) compared a canopy-temperature-based method, the neutron probe method, and the computerassisted method based on evapotranspiration and Kc values in central Washington State. A $70 \%$ soil water depletion was allowed before starting irrigation. They concluded that the most practical method was the computer- assisted method using estimates of evapotranspiration and Kc values.

While these techniques have been successfully used in the western regions, their current use in the southeastern United States is limited. Scheduling irrigation based on $\mathrm{Kc}$ values developed in Oregon with the JensenHaise (1963) and Penman (1963) equations required daily inputs of maximum and minimum temperature, dew point, miles of wind, and solar radiation (Hane and Pumphrey, 1984). These weather inputs are not always readily available. Scheduling irrigation based on a set frequency is suitable for dry climates (Kincaid et al., 1993), but is unpractical in subhumid regions where heavy rainfall often occur in the spring. Due to implementation difficulties, methods based on SWT (Curwen 1993; Shock et al., 1998) or canopy temperature (Stockle and Hiller, 1994) are not likely to be used by small farmers.

Another method to schedule irrigation for vegetables is to couple the water balance method to monitor water availability with a crop factor to estimate daily crop water use from class A pan evaporation data. Such crop models have been developed and validated in the Southeast for several crops, including tomato (Lycopersicon esculentum Mill.) (Locascio and Smajstrla, 1996), snap bean (Phaseolus vulgaris L.) (Smittle et al., 1990a), turnip green (Brassica rapa L.) (Simonne et al., 1993), and sweetpotato [Ipomoea batatas (L.) Poir.] (Thompson et al., 1992).

As most small vegetable growers do not have access to overhead irrigation for potato production, drip irrigation may be an economical method for this crop. Therefore, the objectives of this research were to: 1) develop and test an irrigation scheduling model for drip-irrigated potato; and 2) assess the profitability of drip irrigation for potato production.

\section{Materials and Methods}

Model development. The irrigation scheduling model under evaluation used the water balance technique (Stegeman et al., 1980) and scheduled an irrigation when the cumulative water soil deficit became equal to (or approximated) the allowable water use. The complete model was:

$$
\begin{aligned}
& \begin{array}{l}
(13 \mathrm{DAH}+191) * 0.5 \mathrm{ASW} \\
=\mathrm{D}_{\mathrm{DAH}-1}+\left[\mathrm{Ep}^{*}(0.12+0.023 \mathrm{DAH}\right. \\
\left.\left.\quad-0.00019 \mathrm{DAH}^{2}\right)-\mathrm{R}_{\mathrm{DAH}}-\mathrm{I}_{\mathrm{DAH}}\right] \mathrm{Ep} .[1] \\
\text { where } \\
\text { DAH }=\text { days after hilling (days), } \\
\mathrm{ASW}=\text { the available soil water }\left(\mathrm{mm} \cdot \mathrm{mm}^{-1}\right), \\
\mathrm{D} \quad=\text { the soil water deficit }(\mathrm{mm}), \\
\mathrm{Ep} \quad=\text { class A pan evaporation }(\mathrm{mm}), \\
\mathrm{R}_{\mathrm{DAH}}=\text { rainfall }(\mathrm{mm}), \text { and } \\
\mathrm{I}_{\mathrm{DAH}}=\text { irrigation }(\mathrm{mm}) .
\end{array}
\end{aligned}
$$

Hilling potato is a common practice. In this research, the model started after the second (and last) hilling because until then, limited shoot growth occurs, and therefore transpiration is limited. However, the model can also be started at planting. In the model, initial root 
depth was set at $191 \mathrm{~mm}$, which corresponded to the root depth after the second hilling. This depth was estimated (Portas, 1968) and also verified in the field. Root depth was assumed to expand at a daily rate of $13 \mathrm{~mm}$ (Portas, 1968) up to a maximum depth of $305 \mathrm{~mm}$. Root depth calculated as $13 * \mathrm{DAH}+191$ reached $305 \mathrm{~mm}$ on $9 \mathrm{DAH}$.

The allowable use $(13 * \mathrm{DAH}+191) * 0.5$ ASW varied with soil type (ASW content) and increased until a root depth of $305 \mathrm{~mm}$ was attained. The model was evaluated on a Hartsells fine sandy soil (Fine, sandy, siliceous thermic Typic Hapludult) with an available soil water of $0.13 \mathrm{~mm} \cdot \mathrm{mm}^{-1}$. Consequently, the allowable use $(13 * \mathrm{DAH}+191) * 0.5 * \mathrm{ASW}$ ranged between 13 and $20 \mathrm{~mm}$ on 0 and 19 $\mathrm{DAH}$, respectively. The model assumed that water is to be controlled to a $305 \mathrm{~mm}$ soil depth. This depth can be adjusted to depth of tillage.

A crop factor (CF) developed specifically for potato in the Southeast was looked for, but none was found Therefore, the $\mathrm{CF}$, for values changing with plant age, developed for sweet potato, and defined as $\mathrm{CF}=0.12+0.023^{*} \mathrm{DAH}$ $-0.00019 * \mathrm{DAH}^{2}$ (Smittle et al., 1990b), was selected. In addition, shoot development, length of growing season, and production practices are similar for both crops. The values for this $\mathrm{CF}$ ranged between 0.12 on $0 \mathrm{DAH}$ to 0.82 on $63 \mathrm{DAH}$

A practical method to calculate daily water budgets is to use a tabular format (Smittle and Dickens, 1992) with columns headings of age, root depth, date, class A pan evaporation, crop factor, daily use, rain, adjusted use, cumulative water use, and allowable water use (Table 1 ). To operate the model, CF and allowed water use values were computed for each day. Date, pan evaporation, and total rainfall were then recorded daily. Pan evaporation was multiplied by $\mathrm{CF}$ to compute Daily Use, and rainfall was subtracted from daily use to calculate Daily Adjusted Use (if no rain, then Daily
Adjusted Use $=$ Daily Use). When rainfall amount exceeded soil water depletion, Daily Adjusted Use was reset to 0 as the amount of water that can be stored in the soil each day cannot exceed soil water depletion on that day. Then, Daily Adjusted Use of the current day was added to the Cumulative Adjusted Use. Cumulative Adjusted Use was set to 0 when rainfall exceeded soil water deficit at the time of the rain (Cumulative Adjusted Use should not become negative). The model predicted an irrigation on the day Cumulated Adjusted Use equals Allowed Use. The water amount applied was equal to the Cumulative Adjusted Use of that day. After an irrigation, Cumulative Adjusted Use was reset to 0 .

Model testing. Model testing consisted of creating a water gradient, scheduling irrigation according to the model, and recording yield response to water application rates. The model would be considered acceptable if yields are highest in the area receiving $100 \%$ of the model rate.

Water was applied through drip irrigation (T-Tape, $8 \mathrm{~mL}, 1 \mathrm{~L} / \mathrm{min} / 30 \mathrm{~m}$ ). Seven beds with several controlled irrigation levels were created. The irrigation level ranged between $53 \%$ and $200 \%$ of the model rate. A treatment with no irrigation was used as a control and considered as $0 \%$ of the model rate. To reduce irrigation duration, two drip-tapes were placed $30 \mathrm{~cm}$ apart on the beds receiving water rates higher or equal to $100 \%$, and one drip tape on the others. To measure the water amounts applied, buckets were buried under two consecutive emitters. Because of the surface wetted by each emitter, a volume of $2.6 \mathrm{~L}$ collected by the buckets corresponded to a $19-\mathrm{mm}$ water application rate over the bed.

Potato crop. This experiment was conducted in 1996 and 1998, and cultural practices were similar each year. The soil was harrowed and subsoiled to a 305-mm depth. As recommended, soil $\mathrm{pH}$ was $\approx 5.5$ to reduce the incidence of scab disease. Preplant fertili- zation consisted of a broadcast application of $956 \mathrm{~kg} \cdot \mathrm{ha}^{-1}$ of a $5 \mathrm{~N}-4.4 \mathrm{P}-12.5-\mathrm{K}$ fertilizer. The soil was then rototilled to a $153-\mathrm{mm}$ depth. Seed pieces of 'Red LaSoda' were planted on 9 Apr. 1996 and 7 Apr. 1998, in 6.2-m-long, single-row plots, at a $30.5-\mathrm{cm}$ within-row spacing.

Plants were sidedressed with ammonium nitrate on 15 May $(\mathrm{DAH}=2)$ and 14 June $(\mathrm{DAH}=31)$ in 1996, and on 20 Apr. (DAH $=-10)$ and 1 May $(\mathrm{DAH}=0)$ in 1998. Each time, $\mathrm{N}$ rates were 39 and $56 \mathrm{~kg} \cdot \mathrm{ha}^{-1}$ for the 1.00 and 1.25 recommended $\mathrm{N}$ rates, respectively (Adams et al., 1994). Total $\mathrm{N}$ fertilization was 135 and $168 \mathrm{~kg} \cdot \mathrm{ha}^{-1}$ for the recommended and high $\mathrm{N}$ rate, respectively. Insect and disease control practices followed the recommendations of the Alabama Cooperative Extension System for potato production (Zhender et al., 1996).

Plants were hilled on 1 May $(\mathrm{DAH}=-13)$ and 14 May $(\mathrm{DAH}=0)$ in 1996, and on $20 \mathrm{Apr}$. $(\mathrm{DAH}=-10)$ and 1 May $(\mathrm{DAH}=0)$ in 1998. Tubers were harvested on 85 DAH in 1996, and $82 \mathrm{DAH}$ in 1998. They were graded and weighed as Extra US\#1 (5 to $9 \mathrm{~cm}$ diameter; 8 to $23 \mathrm{~cm}$ length), US\#1 (2.5 to $5 \mathrm{~cm}$ diameter; 5 to $18 \mathrm{~cm}$ length), US\#2 (tubers having diameter or length $>3.81 \mathrm{~cm}$ ), and culls (damaged tubers, or diameter $<3.87 \mathrm{~cm}$ ).

The experimental design was a split-plot design with four replications. Nitrogen fertilization was the main plot, and irrigation rates the sub-plots. The significance of the irrigation rate, $\mathrm{N}$ fertilization rate, and their interaction was determined with analysis of variance (ANOVA). Mean yield response to irrigation rates was determined with regression analysis (control included).

Economical return. The potential economical return was calculated by subtracting the cost of irrigation from the dollar value of the yield increase due to irrigation. The cost of irrigation was estimated at $\$ 600 /$ ha to cover the cost of water, and drip-tape purchase and

Table 1. Tabular format of irrigation scheduling model for potato between 38 and 53 DAH in 1996.

\begin{tabular}{|c|c|c|c|c|c|c|c|c|c|c|}
\hline $\mathrm{Age}^{\mathrm{z}}$ & $\begin{array}{c}\text { Root depth } \\
(\mathrm{mm})\end{array}$ & Date & $\begin{array}{c}\text { Pan Evap. } \\
(\mathrm{mm})\end{array}$ & $\begin{array}{c}\text { Crop } \\
\text { factor }^{\mathrm{x}}\end{array}$ & $\begin{array}{l}\text { Daily use } \\
(\mathrm{mm})\end{array}$ & $\begin{array}{l}\text { Rain } \\
(\mathrm{mm})\end{array}$ & $\begin{array}{c}\text { Adj. use }{ }^{w} \\
(\mathrm{~mm})\end{array}$ & $\begin{array}{c}\text { Cum.adj. } \\
\text { use }^{\mathrm{w}}(\mathrm{mm})\end{array}$ & $\begin{array}{l}\text { All. } \text { use }^{v} \\
(\mathrm{~mm})\end{array}$ & $\begin{array}{c}\text { Irrigation } \\
(\mathrm{mm})\end{array}$ \\
\hline 38 & 305 & $6 / 20$ & 3 & 0.72 & 2 & 3 & -1 & 15 & 20 & 0 \\
\hline 39 & 305 & $6 / 21$ & 6 & 0.73 & 4 & 1 & 3 & 18 & 20 & 20 \\
\hline 40 & 305 & $6 / 22$ & 10 & 0.74 & 7 & 0 & 7 & 7 & 20 & 0 \\
\hline 41 & 305 & $6 / 23$ & 10 & 0.74 & 7 & 0 & 7 & 14 & 20 & 0 \\
\hline 42 & 305 & $6 / 24$ & 2 & 0.75 & 2 & 5 & -3 & 11 & 20 & 0 \\
\hline 43 & 305 & $6 / 25$ & 13 & 0.75 & 10 & 0 & 10 & 21 & 20 & 25 \\
\hline 44 & 305 & $6 / 26$ & 4 & 0.76 & 3 & 0 & 3 & 3 & 20 & 0 \\
\hline 45 & 305 & $6 / 27$ & 3 & 0.77 & 2 & 0 & 2 & 5 & 20 & 0 \\
\hline 46 & 305 & $6 / 28$ & 6 & 0.77 & 7 & 0 & 5 & 10 & 20 & 0 \\
\hline 47 & 305 & $6 / 29$ & 6 & 0.78 & 5 & 0 & 5 & 15 & 20 & 0 \\
\hline 48 & 305 & $6 / 30$ & 10 & 0.78 & 8 & 0 & 8 & $23^{\mathrm{u}}$ & 20 & 0 \\
\hline 49 & 305 & $7 / 1$ & 8 & 0.79 & 6 & 0 & 6 & 29 & 20 & 27 \\
\hline 50 & 305 & $7 / 2$ & 7 & 0.80 & 6 & 0 & 6 & 6 & 20 & 0 \\
\hline 51 & 305 & $7 / 3$ & 8 & 0.80 & 6 & 0 & 6 & 12 & 20 & 0 \\
\hline 52 & 305 & $7 / 4$ & 7 & 0.80 & 6 & 4 & 2 & 14 & 20 & 0 \\
\hline 53 & 305 & $7 / 5$ & 9 & 0.80 & 7 & 4 & 3 & 17 & 20 & 0 \\
\hline
\end{tabular}

${ }^{2}$ DAH $=$ Days after hilling.

${ }^{\mathrm{y}}$ Class A Pan Evaporation (Evap.).

${ }^{\mathrm{x}}$ Crop factor $=0.12+0.023 * \mathrm{DAH}-0.00019 * \mathrm{DAH}^{2}$

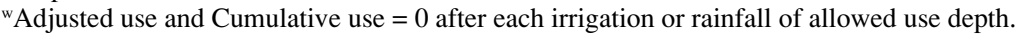

${ }^{v}$ Allowed use $=(0.5 * \mathrm{DAH}+7.5) * 0.5 * \mathrm{ASW}$ and ASW $=0.13$ for a Hartsells fine sandy soil

"An irrigation was scheduled on $48 \mathrm{DAH}$. It was postponed due to high chances of rain on that day. As it did not rain, the irrigation was applied the next day. 
installation (This does not include the cost of filtration and pumping equipment purchase and maintenance). The yield increase due to irrigation was calculated separately for each year from the production function estimating marketable yield from water application rate, by subtracting the yield of the nonirrigated crop (intercept) from the maximum yield. To determine maximum yield, the first derivative of the quadratic function describing yield responses to water application rate was calculated; then, the water application rate that corresponded to a first derivative of 0 was determined; finally, maximum yield was calculated using that water application rate. A price of $\$ 220 / \mathrm{t}$ for June sales of potato was used (Witzig and Pugh, 2000) to determine yield value.

\section{Results and Discussion}

Rainfall and water application rates. Because of different weather patterns, results are presented separately for each year. In 1996, total rainfall was $170 \mathrm{~mm}$ and excessive rainfall events occurred on 20,30,57, and $61 \mathrm{DAH}$ (excessive amounts were 13, 9, 3, and $4 \mathrm{~mm}$, respectively), for a total amount of $29 \mathrm{~mm}$. Rainfall was considered excessive when it was larger than the soil water deficit at the time of the rain. That year, the model called for five irrigations. For the $100 \%$ model rate, water amounts applied at each irrigation were 19,20, 25 , and $27 \mathrm{~mm}$ on $35,39,43$, and $49 \mathrm{DAH}$, respectively. An irrigation of $21 \mathrm{~mm}$ was scheduled on 60 DAH but was delayed due to a rainfall of $11 \mathrm{~mm}$ on that day. Water application rates were $0 \%, 60 \%, 80 \%, 100 \%, 120 \%$, $140 \%$, and $160 \%$ of the model rate (Table 2). As observed in similar work (Simonne et al, 1993; Smittle et al., 1990b), the water application rates were slightly different each year, mainly due to differences in irrigation system configurations as different fields were used each year. Yet, the determination of water application rates from actual application amounts (rather than from irrigation treatment numbers) allowed to take into account these differences.

In 1998, total rainfall was $221 \mathrm{~mm}$. Seven irrigations were scheduled by the model on 33 , $42,48,54,58,62$, and $64 \mathrm{DAH}$, in amounts of $14,15,15,15,20,15$, and $15 \mathrm{~mm}$, respectively, for a total of $109 \mathrm{~mm}$. Even though total rainfall was higher in 1998 than in 1996, the model called for more irrigations in 1998 than in 1996. This was due to a different rainfall distribution and emphasizes the importance of real-time irrigation decision in subhumid areas like the Southeast. Water application rates in 1998 were $0 \%, 53 \%, 87 \%, 100 \%, 130 \%$, $160 \%$, and $200 \%$ of the model rate (Table 2).

Tuber yield response to water application rates. The interaction between water application rate and $\mathrm{N}$ rate was nonsignificant ( $P$ values ranging between 0.25 and 0.74 ) for all grades in 1996 and 1998. Therefore, the effects of water application rates and $\mathrm{N}$ rates are discussed separately.

The responses of total and marketable yields to water application rates were signifi-

Table 2. Water applied ( $\mathrm{mm}$ ) and water application rates (percentage of the model rate) in 1996 and 1998.

\begin{tabular}{lccccc}
\hline & \multicolumn{2}{c}{1996} & & \multicolumn{2}{c}{1998} \\
\cline { 2 - 3 } \cline { 5 - 6 } Bed \# & $\begin{array}{c}\text { Total water } \\
\text { amount }(\mathrm{mm})\end{array}$ & $\begin{array}{c}\text { Irrigation } \\
\text { rate }(\%)\end{array}$ & & $\begin{array}{c}\text { Total water } \\
\text { amount }(\mathrm{mm})\end{array}$ & $\begin{array}{c}\text { Irrigation } \\
\text { rate }(\%)\end{array}$ \\
\hline 1 & 151 & 160 & & 215 & 200 \\
2 & 129 & 140 & & 172 & 160 \\
3 & 107 & 120 & & 136 & 127 \\
4 & 93 & 100 & & 107 & 100 \\
5 & 72 & 80 & & 93 & 87 \\
6 & 57 & 60 & & 57 & 53 \\
7 & 0 & 0 & & 0 & 0 \\
\hline
\end{tabular}
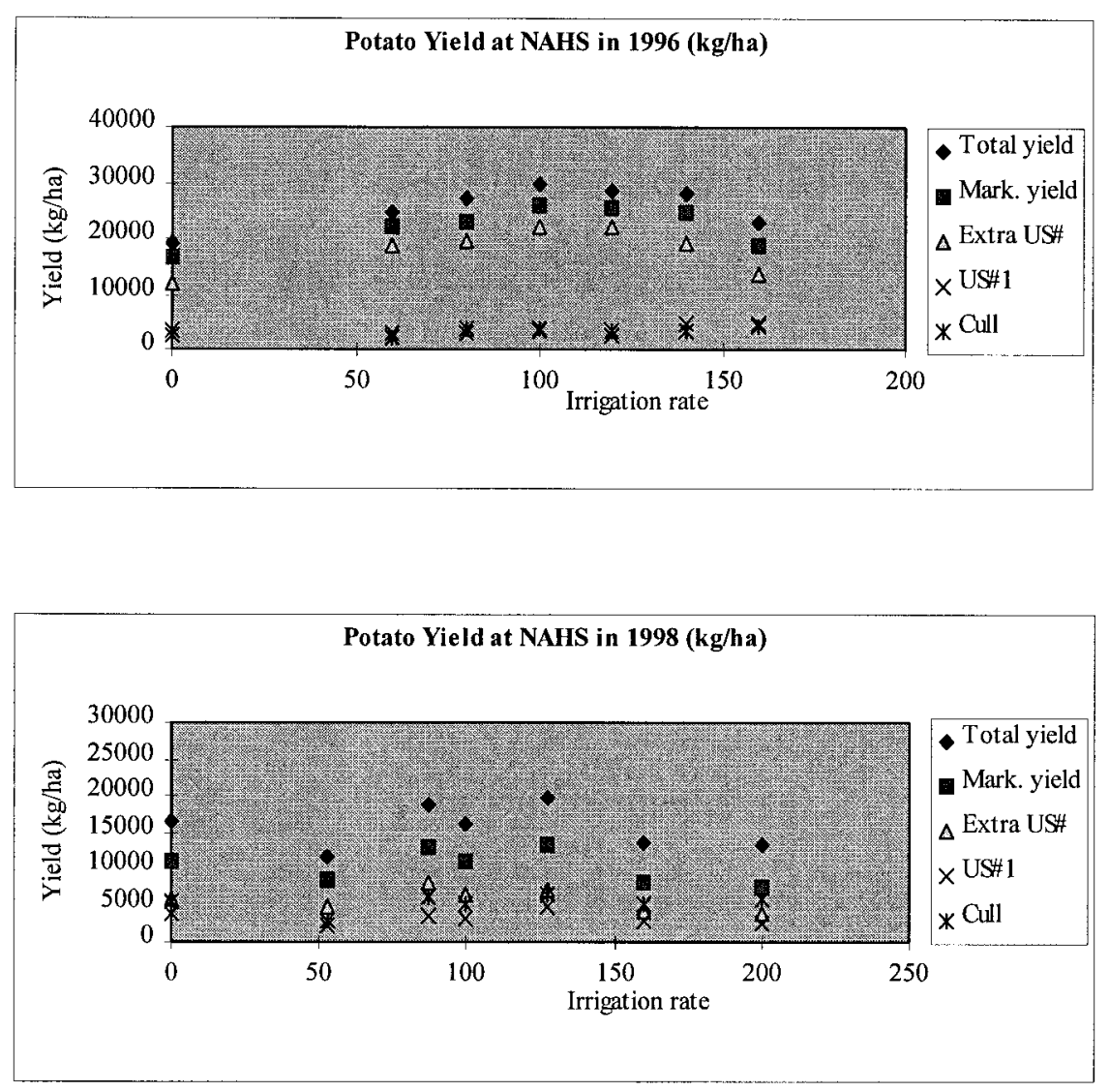

Fig. 1. Potato yield response to water application rates in 1996 and 1998. NAHS = North Alabama Horticulture Substation.

cant (all $P$ values $<0.01$ ) for both years. The significant quadratic relation between total yield (TYLD, in $\mathrm{kg} / \mathrm{ha}$ ) and water application rates (WAR) were described as TYLD $_{96}=$ $18417+197 \mathrm{WAR}-0.990 \mathrm{WAR}^{2}$ in 1996 , and $\mathrm{TYLD}_{98}=14798+42 \mathrm{WAR}-0.245 \mathrm{WAR}^{2}$ in 1998(Fig. 1). Highest total yields were obtained for irrigation rates of $99 \%$ and $86 \%$, in 1996 and 1998, respectively. Marketable yield $\left(\mathrm{MKYLD}\right.$, in $\left.\mathrm{kg} \cdot \mathrm{ha}^{-1}\right)$ response to water application rates was MKYLD M6 $_{96}=15784+189$ WAR - 0.993 WAR ${ }^{2}$ in 1996, and MKYLD 98 $=9894+41 \mathrm{WAR}-0.266 \mathrm{WAR}^{2}$ in 1998 (Fig. 1). Highest marketable yield was obtained for irrigation rates of $95 \%$ and $76 \%$ of the model rate in 1996 and 1998, respectively.

In 1996, similar results were observed with the extra US\#1 and US\#1 grades $(P=0.01$ and 0.03 , respectively). However, cull weight re- sponse to water application rate was not significant $(P=0.14)$. The highest extra US\#1 yield occurred with the $100 \%$ water application rate. The proportion of extra US\#1 yield in relation to marketable yield was $62 \%$ and $84 \%$ for the $0 \%$ and $100 \%$ water application rate, respectively. These results suggest that in 1996, the increase in marketable yield was mainly due to an increase in yield of the premium extra US\#1 grade.

In 1998, grade responses to water application rates were nonsignificant $(P$ value $>0.07)$, including for cull $(P=0.11)$. Yet, the proportion of extra US\#1 potatoes in relation to marketable potatoes increased with irrigation and was $49 \%$ and $58 \%$ of the marketable yield for $0 \%$ and $100 \%$ of the model rate, respectively.

These results suggest that scheduling irrigation according to the model rate increased 
potato total and marketable yield, as well as the proportion of US\#1 grade. As highest yields were $99 \%$ and $86 \%$ of the model rate, it was concluded that the irrigation scheduling model was a practical tool to schedule irrigation, but may need further site-specific adjustments.

Tuber yield response to $N$ rates. Total, marketable, Extra US\#1, and cull yields were 24.9 and 26.5, 21.4 and 23.3, 17.6 and 18.5, and 3.5 and 3.2 in 1996; and 14.4 and 16.8, 8.9 and $11.6,4.9$ and 6.6 , and 5.5 and $5.3 \mathrm{t} / \mathrm{ha}$ in 1998 , for the 1.00 and 1.25 recommended $\mathrm{N}$ rates, respectively. For both years, yields tended to be higher with the high $\mathrm{N}$ treatment as compared to the recommended rate. Yet, these differences were significant only for marketable and US\#1 yield $(P=0.03$ and 0.01 , respectively) in 1996, and for marketable $(P=0.01)$, and extra US\#1 $(P=0.03)$ yield in 1998. These results suggest that the current $\mathrm{N}$ recommended rate for potato (135 $\mathrm{kg} / \mathrm{ha}$ ) (Adams et al., 1994) may not be sufficient when irrigation is used, as significantly higher marketable yields were obtained with a N rate of $168 \mathrm{~kg} / \mathrm{ha}$ both years. As only two $\mathrm{N}$ rates were used in this study, further research is needed to determine optimum $\mathrm{N}$ rate for drip-irrigated potato.

Economical feasibility of drip-irrigation for potato. Yearly marketable yield increases due to irrigation were 9,012 and $1,580 \mathrm{~kg} \cdot \mathrm{ha}^{-1}$, in 1996 and 1998, respectively. Using a $\$ 220 /$ ton estimated market value for June sales, this 2-year average of 5,286 $\mathrm{kg} \cdot \mathrm{ha}^{-1}$ translated to an estimated increased value of $\$ 1,163 /$ ha each year irrigation was used. Additional costs due to irrigation were estimated at $\$ 600 /$ ha. These estimates show a potential $\$ 563 /$ ha net profit due to irrigation. Actual estimates may vary, depending on market price and actual water cost.

This estimated benefit ( $\$ 563 /$ ha) was high because irrigation was needed in 1996 and 1998. Weather patterns in the Southeast are such that irrigation may not be needed every year. Yet, as drip tubing needs to be installed at hilling, growers need to incur most of the irrigation cost before they know if irrigation will be needed. As summer months are usually dryer in the Southeast, these results suggest that a higher potential profit due to irrigation may be expected for late (summer) plantings of potato. Reduced cost may be expected if drip-tape is used more than once.

It was shown that yield and quality of potato grown in a fine sandy soil were increased by irrigation. Furthermore, an irrigation scheduling model using the water balance method and adjusting irrigation to class A pan evaporation and rainfall data was developed and tested. The model can be adapted to different soil types and tillage depths. The model is not dependant on long-term weather data as it uses real-time weather inputs such as class A pan evaporation and rainfall. Yet, this model needs to be tested on-farm under different production situations including soil types, potato type, and fertilization program. These results also suggest that the recommended $\mathrm{N}$ rate for dryland potato may not be sufficient for drip-irrigated production. Over the 2-year period of the experiment, using drip-irrigation resulted in a net increased value of $\$ 563 / \mathrm{ha}$, suggesting that this practice can be economical.

\section{Literature Cited}

Adams, J.F., C.C. Mitchell, and H.H. Bryant. 1994. Soil test fertilizer recommendations for Alabama crops. Agr. Soils. Dept. series no. 178, Alabama Agr. Expt. Sta., Auburn Univ.

Curwen, D. 1993. Water management, p. 67-75. In: R.C. Rowe (ed.). Potato health management. APS Press, St. Paul, Minn.

Hane, D.C. and F.V.Pumphrey. 1984. Yield-evapotranspiration relationships and seasonal crop coefficients for frequently irrigated potatoes. Amer. Potato J. 61:661-667.

Jensen, M.E. and H.R. Haise. 1963. Estimating evapotranspiration from solar radiation. J. Irr. Drain. Div., Amer. Soc. Civil. Eng. 89:15-41.

Kincaid, D.C., D.T. Westermann, and T.J. Trout. 1993. Irrigation and soil temperature effects on Russet Burbank quality. Amer. Potato J. 70:769-777.

Locascio, S.J. and A.G. Smajstrla. 1996. Water application scheduling by pan evaporation for drip-irrigated tomato. J. Amer. Soc. Hort. Sci. 121:63-68.

Miller, D.E. and M.W. Martin. 1985. Effect of water stress during tuber formation on subsequent growth and internal defects in Russet Burbank potatoes. Amer Pot. J. 62:83-89.

Miller, D.E. and M.W. Martin. 1987. Effect of declining or interrupted irrigation on yield and quality of three potato cultivars grown on a sandy soil. Amer. Potato J. 64:109-107.

Penman, J.L. 1963. Vegetation and hydrology. Commonwealth Bureau of Soils, Harpenden, U.K. Tech. Comm. No. 53, p. 1-125.
Portas, C.A.M. 1968. Development of root system during the growth of some vegetable crops. Plant \& Soil 39:507-518.

Shock, C.C., E.B.G. Feibert, and L.D. Saunders. 1998. Potato yield and quality response to deficit irrigation. HortScience 33:655-659.

Shock, C.C., Z.A. Holmes, and T.D. Steiber. 1993. The effect of timed water stress on quality, total solids and reducing sugar content of potatoes. Amer. Potato J. 70:227-241.

Smittle, D.A. and W.L. Dickens. 1992. Water budgets to schedule irrigation for vegetables. HortTechnology 2:54-59.

Smittle, D.A., W.L. Dickens, and J.R. Stansell. 1990a. An irrigation scheduling model for snap bean. J. Amer. Soc. Hort. Sci. 115:226-230.

Smittle, D.A., M.R. Hall, and J.R. Stansell. 1990b. Effect of irrigation regimes on yield and water use by sweetpotato. J. Amer. Soc. Hort. Sci. 115:712-714.

Simonne, E.H., D.A. Smittle, and H.A. Mills. 1993. An irrigations scheduling model for turnip greens. J. Amer. Soc. Hort. Sci. 118:726-730.

Stark, J.C. and I.R. McCann. 1992. Optimal allocation of limited water supplies for Russet Burbank potatoes. Amer. Potato J. 69:413421

Stark, J.C., J.C. Ojala, and I.R. McCann. 1987. Estimation of diurnal changes in potato leaf water potential under irrigated conditions. J. Amer. Soc. Hort. Sci. 112:825-829.

Stegeman., E.C., J.R. Musick, and J.I. Steward. 1980. Irrigation water management, p. 763816. In: M.E. Jensen (ed.). Design and operation of farm irrigation systems. Amer. Soc. Agr. Eng., St. Joseph, Mich.

Stockle, C.O. and L.K. Hiller. 1994. Evaluation of on-farm irrigation scheduling methods for potatoes. Amer. Potato J. 71:155-164.

Thompson, P.G., D.A. Smittle, and M.R. Hall. 1992. Relationship of sweetpotato yield and quality amount. HortScience 27:23-26.

Weisz, R, J. Kaminski, and Z. Smilowitz. 1994. Water deficit effects on potato leaf growth and transpiration: Utilizing fraction extractable soil water for comparison with other crops. Amer. Potato J. 71:829-840.

Witzig, J.D. and N.L. Pugh. 2000. Florida agricultural statistics: 1998-1999 vegetable summary. Florida Agr. Stat. Serv., Orlando, Fla.

Wolfe, D.W., E. Fereres, and R.E. Voss. 1983. Growth and yield responses of two potato cultivars to various levels of applied water. Irr. Sci. 2:211-222.

Zehnder, G., E.J. Sikora, M.G. Patterson, J.W. Everest, J. Kemble, and R. Boozer. 1996. Insect, disease, nematode and weed control recommendations. Alabama Coop. Ext. Sys. Bul. IPM96-2, Auburn Univ., Ala. 